Why do youth get hurt, sick, or killed on the job?

Teens work in a variety of industries, from food service to farming. They get hurt at twice the rate of adult workers. Employers are responsible for making workplaces safe. But youth often lack proper supervision, safety awareness, and training.

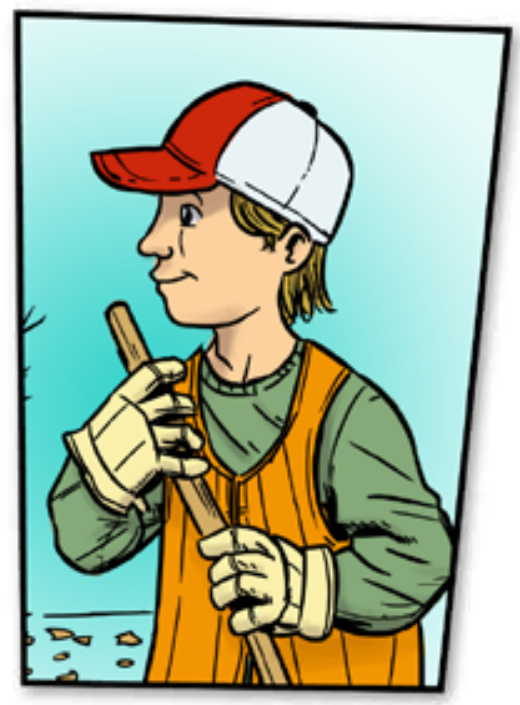

\section{True Stories}

- 17-year-old Darnell lost a finger in a food shredder at a fast food restaurant.

- 16-year-old Maria was robbed and assaulted at gunpoint while working alone at a clothing shop.

- 15-year-old Katie suffered a severe burn while working as a barista.

- 14-year-old Wayne died after falling into a feed grinder while working on a farm.
What teachers say about Talking Safety

"It opened a lot of eyes!"

Florida

"The kids loved talking about their jobs." Illinois

"Students loved the games, the skits and the role play!"

Louisiana

\section{Bring Talking Safety to school today.} Save a life tomorrow.

\section{Where can I get more information?}

Refer to the following sources for more information about young worker safety and health topics:

Young Worker Safety and Health

www.cdc.gov/niosh/topics/youth/

\section{Talking Safety}

www.cdc.gov/niosh/talkingsafety/

\section{NIOSH}

Telephone: 1-800-CDC-INFO (1-800-232-4636)

TTY: 1-800-232-6348 | E-mail: cdcinfo@cdc.gov

CDC-INFO: http://wwwn.cdc.gov/dcs/RequestForm.aspx

NIOSH Website: www.cdc.gov/niosh

For a monthly update on news at NIOSH, subscribe to NIOSH eNews by visiting www.cdc.gov/niosh/eNews

February 2015

Illustration credits: Chi-Yun Lau

SAFER • HeAlthier • PeOPLE ${ }^{\text {TM }}$

DHHS (NIOSH) Publication No. 2015-110
YOUTH@WORK

\section{Talking Safety}
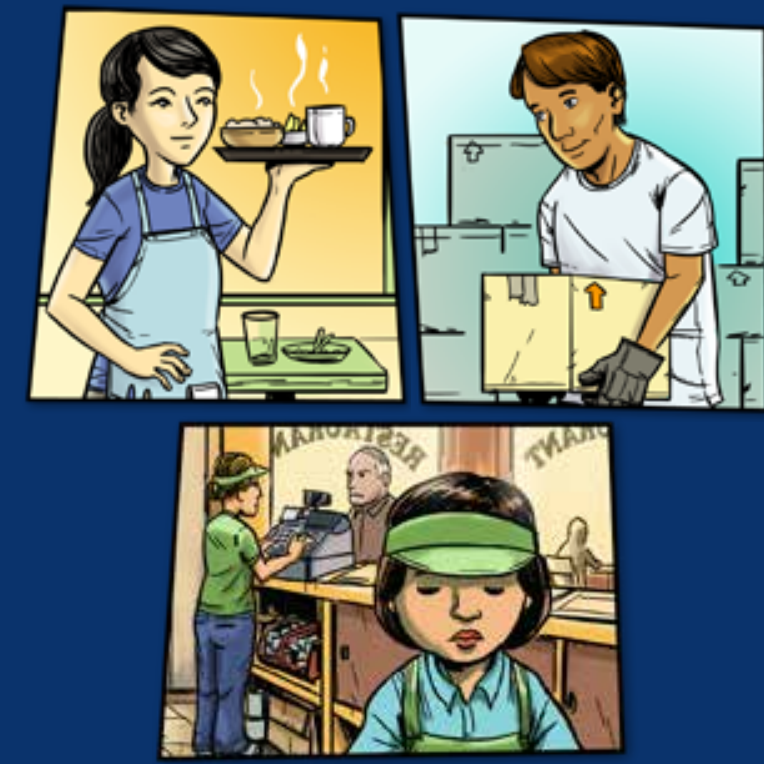

A free, fun, and fast curriculum for middle and high schools

Giving youth work readiness skills to keep them safe and healthy

DEPARTMENT OF HEALTH AND HUMAN SERVICES Centers for Disease Control and Prevention National Institute for Occupational Safety and Health 


\section{What is Talking Safety?}

Talking Safety is a free, interactive, curriculum that teaches essential work readiness skills to middle and high school students. The curriculum helps young people to:

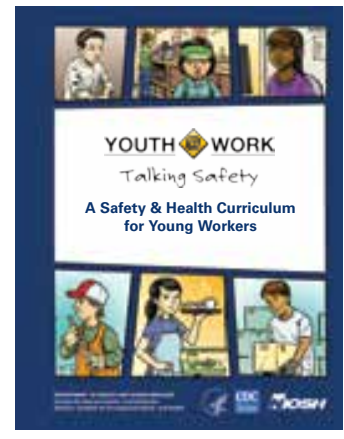

- Receive vital work readiness skills they can use in any workplace, now and in the future.

- Increase their awareness of workplace safety risks and hazards.

- Communicate with employers and protect themselves from job hazards.

- Know their rights and responsibilities on the job.

- Have a positive and active attitude toward workplace safety and health.

- Know how to respond to emergencies on the job.

\section{It contributes to academic performance.}

Studies show that when a teen is hurt on the job, $\mathrm{s} /$ he can experience a negative impact on academic performance. Keeping youth healthy and safe on the job is crucial to helping them succeed in the classroom.

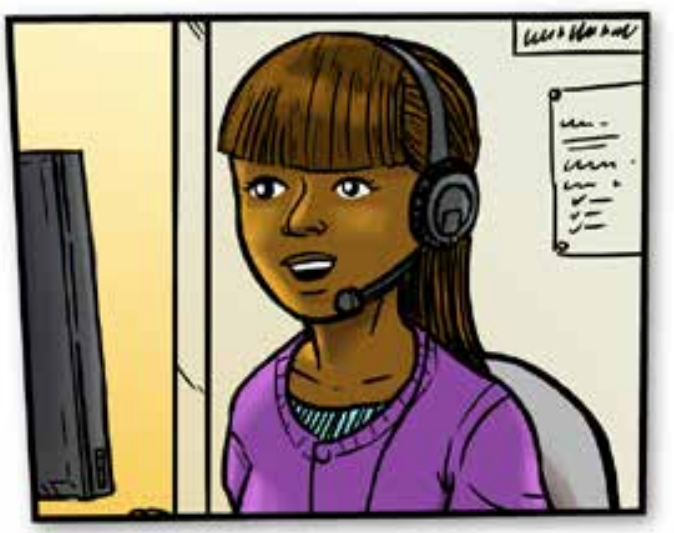

\section{What can you do to protect teen workers?}

Make Youth@Work: Talking Safety part of the school health and work readiness programs in your district.

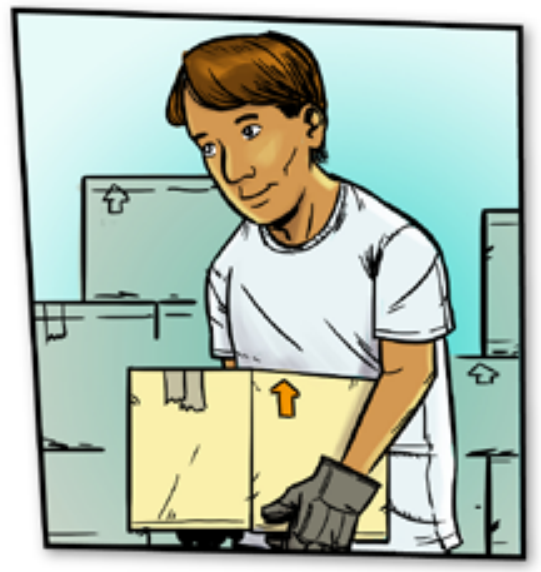

\section{It fits into school health and work readiness programs.}

Talking Safety is aligned with the Centers for Disease Control and Prevention's (CDC's) National Health Education Standards (NHES), the Common Core State Standards (CCSS), and the Common Career Technical Core (CCTC).

You can also use Talking Safety in career education/work readiness programs, internship programs, and in other training situations for young workers.

\section{Does Talking Safety work?}

Yes! The curriculum was pilot tested in 16 high schools across the United States. It was shown to increase students' knowledge of workplace safety and health and gave them vital skills for protecting themselves on the job.

\section{Did you know?}

Every minute, a young person in the United States is injured on the job.

By the time they finish high school, $80 \%$ of U.S. teens have held a job. But the vast majority of them enter the workforce unprepared for the challenges-and hazards-they face.

Use the free, Youth@Work: Talking Safety curriculum from the National Institute for Occupational Safety and Health, (NIOSH) to give your students the vital work readiness skills they need to stay safe and healthy on the job now-and throughout their lives. 